UDC 004:378-057.21

DOI: https://doi.org/10.30839/2072-7941.2018.149669

\title{
THE ROLE OF INFORMATION AND COMMUNICATION TECHNOLOGIES IN THE SYSTEM OF FORMING OF PROFESSIONAL COMPETENCES OF ENGINEERS
}

\author{
(C) VASILENKO, T. H. \\ Zaporizhzhia State Engineering Academy (Zaporizhzhia, Ukraine) \\ E-mail: tatyana.vasilenko2012@gmail.com, ORCID 0000-0001-6166-0617 \\ (C) DOBROVOLSKA, O. H. \\ Zaporizhzhia State Engineering Academy (Zaporizhzhia, Ukraine) \\ E-mail: dogoks@gmail.com, ORCID 0000-0002-1337-7216
}

\begin{abstract}
Actuality of the conducted research is practically oriented character. Without the use of information and communication technologies (ICTs) in the field of higher education, it is impossible to carry out qualitative training of specialists in engineering, the results of which are necessary for the implementation of a national strategy for modernizing the economy and forming a progressive state of European type. Formulation of the task - the specificity of the use of ICT in the system of higher education has not been studied sufficiently. ICT form a complex environment, which includes a lot of information objects and the links between them. It can be argued that the structural and functional analysis of the use of ICT in higher education is the basis of the theoretical justification in the formation of technical professionalism of future engineers. ICTs form a complex system, which includes not only technical and software-hardware capabilities, but also psycho-pedagogical, organizational, methodological. Without taking into account all of these components, as well as the needs of the subjects of the educational process, the use of ICT tools (especially centralized) may be accompanied by risks and negatively affect the quality of high education. An analysis of recent research and publications-is actively exploring the experience of using ICT in high school, it is possible to distinguish the work of foreign specialists D. Stevenson, G. Reinhold, E. Wenger, S. Papierta, I. Zakharova, E. Patarakina, A. Khutorskogo, E. Polat The founders of this scientific direction in our country were M. I. Zhaldak, Y. I.Mashbits. The recent significant increase in the number of studies, the subject of which was the use of information and communication technologies in the educational process. Tsitemi in Ukraine is dedicated to the study of such scholars as V. Yu. Bykov, Ya.V. Bulakhova, O.M. Bondarenko, V.F. Zabolotny, G.O. Kozlakova, O. Moiko, O. Naumenko, Yu.Burovitskaya, I. Stavyts'ka, O.P. Pinchuk, O.V. Shestopal and others. Selection of unexplored parts of the general problem. The use of information technologies in the educational process is the foundation of innovative development of the educational system. The rapid development of ICT provides not only significant pace of innovative progress, but also requires the definition (limitation) of information resources that guarantee the quality of learning, the choice of techniques that are in line with the general strategy for the formation of professional competences. Therefore, the problem of choosing an approach to the process of learning with the use of ICTs remains one of the main tasks of education. Research methods. In theory and practice, the study of the application of information and communication technologies (ICT) in high school uses empirical methods of collecting and analyzing information based on the results of the survey of 120 students. Presenting main material. The essence of professionalism of future specialists of the technical direction is revealed. The scientific point
\end{abstract}

(C) Vasilenko, T. H. Dobrovolska, O. H., 2018 
of view on the professionalism of the engineer is presented. The peculiarities of formation of the basis of technical professionalism of future engineers in the process of studying at a higher school are theoretically grounded. The quantitative and qualitative analysis of the results of empirical researches of this problem is presented. The practical significance of the research topic is that the innovative approaches to the training of specialists in engineering specialties are differentiated, which differentiate in the educational concepts of teaching in higher educational institutions of European countries.

Key words: engineering education; information and communication technologies; professional competency; integrative-activity training

Analysis of recent research and publications. The experience of ICT using in high school is actively considered, it is possible to distinguish the works of foreign experts, such as D. Stevenson, G. Reinhold, E. Wenger, S. Papiert, I. Zakharova, E. Patarakin, A. Khutorskoy, E. Polat. The founders of this scientific direction in our country were M. I. Zhaldak, Yu. I. Mashbits. Currently, the number of studies has grown significantly, the subject of which was the use of information and communication technologies in the educational process. This topic in Ukraine is devoted to the research of such scholars as V. Yu. Bykov, Y.V. Bulakhova, O.M. Bondarenko, V.F. Zabolotny, G.O. Kozlakova, O.Moyko, O.Naumenko, Yu.Burovitska, I. Stavitskay, O.P. Pinchuk, O.V. Shestopal and others. Selection of unexplored parts of the general problem. Modern economic forms of activity and the transition to the information society form new requirements for the training of engineering specialists. The rapid development of ICT provides not only significant pace of innovation progress, but also requires the introduction of information resources that guarantee the quality of learning, the choice of techniques that are consistent with the general strategy of forming the professional competence of the engineer. Therefore, the problem of choosing certain approaches to the learning process using ICT remains one of the main tasks of education. Research methods. In theory and practice, the study of the application of information and communication technologies (ICT) in high school used empirical methods for collecting and analyzing information based on the results of questionnaires of 120 students. Presenting of the main material. The essence of the competence approach in education of future specialists of technical direction is revealed. The scientific point of view on the approaches to the formation of an engineer professionalism is presented. The peculiarities of forming the fundamentals of technical professionalism of engineers in the process of studying at a higher school are theoretically grounded. The quantitative and qualitative analysis of the results of empirical researches of this problem is presented. The result of the study. In order to solve the problem of ICT coherence with methods of engineering disciplines teaching in higher education, one should create a concept of a strategy for the development of creative learning methods aimed at combining independent work of students using

The role of information and communication technologies in the system of forming of professional competences of engineers 
ICT and face-to-face interaction with a teacher. Conclusions. ICT can significantly change the structure and organization of the learning process, improve the efficiency and quality of learning through the use of resources of the general educational environment, enhance the student's motivation for scientific and cognitive activity. The quality and methodology of ICT implementation in the educational process for the implementation of educational, scientific and organizational activities are important. Therefore, the issue of formation of ICT competence is actual - an important component of the professionalism of both the teacher and the future engineer. Practical meaning. Innovative approaches to the training of specialists of engineering specialties, problems and peculiarities of implementation of ICT in the educational process and motivation of future specialists to independent activity in the process of professional competencies formation are researched.

Key words: engineering education; information and communication technologies; professional competences; motivation in teaching; competent approach.

Introduction. The problem of engineers training at the current stage of Ukraine development is very acute, since the proper ensuring of competitiveness of the national economy, its innovative development and socio-economic development of society as a whole depends on its solution.

Modern economic forms of activity and the transition to the information society form new trends in the manufacturing sector, which requires graduates of higher educational institutions those professional and moral qualities that would allow them to participate effectively in the construction of a modern economic space [1].

It should be noted that the problem of engineering education is not given to the attention it takes in the context of its importance and social actuality due to the significant technological backwardness of the country from the leading economically developed countries of the world [1,2].

The role of engineering education is of paramount importance, since without the development and implementation of innovative technologies resulting from scientific activity, it is impossible to build a socially successful society. In this regard, the construction of a fundamentally new paradigm of engineering education, focused on the formation of professional competences of future professionals, is an urgent and socially important task [2].

Important elements of this training are modern information and communication technologies (ICT), which are part of the country's innovative strategy. The creativity of the engineering specialty involves a high level of education of technical specialists, their possession of intellectual development competences throughout their professional activities. Taking this fact into consideration, it can be argued that the categories of "creativity", "competence", and "information technology" are interrelated. Competent approach in education 
involves the introduction of ICT, taking into account the readiness of higher education, as an institution that should correspond to the modern information space, and students as subjects of the educational process. The existing system of studying at an engineering university is not fully capable of implementing the constructive capabilities of a competent approach, in which the main result is the general and professional competences of the graduate. $[3,4]$.

Analysis of literary data and problem statement.

The definition of the concept of "professional competence" is dealt with by many researchers [5-6]. Summarizing the proposed wording, one can dwell on the following definition: professional competence is the ability and skill of a specialist to function effectively within the framework of his profession and the qualification basis of systematized knowledge and reflexive experience of their application, as well as an innovative type of thinking of a specialist, taking into account axiological approaches to their activities.

The problem of the professional competence of an engineer is formed, on the one hand, by the goals that set the characteristics of the profession and society, and on the other, the individuality of the student himself. The level of formation of the professional competence of an engineer can be determined by many factors: the level of motivation for professional activity; level of professional training; the desire for active self-education; expressed by professionally significant personal qualities; skills of social and cultural communication; a creative approach to their activities; professional experience, etc.

The formation of the above factors is significantly influenced by the use of the educational process of ICT [7]. Under the notion of ICT one must understand a set of methods of production processes, software and hardware integrated to collect, process, store, disseminate, display and use information for the benefit of its users [8]. Interest in the consideration of information and communication processes is due to global trends and is associated with the development of processes of informatization of any activity.

Information and communication technology is a sphere of innovative advancements that is developing at a rapid pace. This process is facilitated by the beginning of the "end of culture, which makes a great deal of people's science and technology alien" [9]. According to G. Reinhold, [10] after the collapse of the 1990s economy of the "soap bubble" in the telecommunications sector, "the infrastructure for creating a global, wireless, Internet-based communications has come to the finish line." If the term "information and communication technology" was first used by D. Stephenson in 1997 in his report to the British government [11], then in 10 years, the president of the World Bank James Wolfenson set out to make his organization a "knowledge bank" - a worldwide resource of high-quality information [

The role of information and communication technologies in the system of forming of professional competences of engineers 
12], and J. Fischer assumed the planning of activities so that students could act not only as passive readers and spectators, but also as active content creators [13]. Later, information technologies were defined as technologies for the dissemination of information and the creation of computer science software [14]. At the present stage, stem-education is developing at the expense of ICT [15]. Questions and problems of the implementation of ICT in the process of engineers training are widely discussed by specialists of different profiles in the context of the goals and practice of educational activities.

On the one hand, ICT, by ensuring the availability of information channels and software products for collecting, storing, transmitting, processing information, allows professionals to focus on an increasing amount of scientific facts and knowledge. It provides the ability to increase the number of participants in the learning process: various forms of implementation of electronic training courses [16]; person-oriented learning technologies [17]. On the other hand, ICTs form a complex environment, which includes many information objects and links between them, which attaches importance to the problem of the effective use of ICT tools and technologies in the modern educational process. In this context, the issues of the formation of professional competences, the development of information literacy as a criterion of competence of modern specialist [18], the formation of the creativity of modern specialists [19], the development of "creative" components in the information economy [20], which corresponds to the strategy of modernizing the national economy on the principles effective use of the creative potential of man were described [21, p. 46]. Along with this, there are a number of important issues related to the problem of motivating students to use ICT in the process of self-study; with the definition of those information resources that guarantee the quality of learning; with the correspondence of the methodology of training the general strategy of formation of professional competences; with feedback provision; with the role of the professionalism and skills of the teacher in the formation of a quality information product.

The aim of the study. The research was carried out in order to determine the level of students' motivation in using ICT in the process of formation of professional competences and the level of activity of self-educational activities, which is necessary for the coordination of ICT with the methodology of teaching engineering disciplines in the process of forming professional competencies; the role of the teacher in the context of the above-mentioned and the definition of the theoretical and practical development of the problem based on the results obtained.

Research methods. In the process of research, an empirical method of information collection and analysis: questionnaires was used. As respondents, the students of the Zaporizhzhia State Engineering Academy were used. The study involved 120 students of the first, second and fifth courses during the school year. 
Research results. The need for the transition to a competent approach in the education of engineers poses complex methodological issues to the teaching staff of higher educational institutions: the coordination of goals and results in the training of engineers in the context of the formation of competences, the creation of appropriate teaching technologies, the development of approaches to assessing the results of training and the quality of training specialists.

This is directly related to the creation of the information and educational environment, electronic educational and methodological products focused on the organization of independent work of students, and those containing professional-oriented tasks that can form a creative approach to their solution. Thus, the application of the innovative method of student preparation raises the question of a practical study of the use of ICT in the learning process.

The study considered the importance of professional training for engineer students: $89.4 \%$ of respondents consider their profession as prestigious and in demand both in Ukraine and in the world, while $91.5 \%$ believe that the main professional competences are formed in the high school.

Assessing the level of students' motivation to use ICT, it was found that $88.7 \%$ of the respondents consider the electronic educational site of the Academy to be an integral part of the training. This is due, above all, to the fact that the advantage of ICT is the timely and rapid receipt of information to the student, the availability and optimality of information.

Students' motivation is also enhanced by the use of various forms of presentation of information, an individual approach to the performance of tasks.

For engineering students, access to software that optimizes the performance of graphic and design tasks is important.

Taking into account the above, the willingness to work independently with the use of ICT is revealed by $79.5 \%$ of the respondents. By the end of the first year students are aware of the opportunities provided by various information resources, through which they can expand their ability to search for special information for more effective mastering of software. Fifthyear students understand exactly that the ability to use ICT is an integral part of their professional success and also in future. During the study, the question about the importance of the ability to work with information through ICT in the context of the formation of professional competencies was raised: $97.8 \%$ associate the formation of a professional level with the search and ability to analyze information and $76.9 \%$ express readiness to continuously improve the experience with special technical information. The experience of self-realization when performing meaningful professional tasks and determining their approach to their implementation leads to the formation of competencies.

It should be noted that $56.3 \%$ of respondents believe that the use of 
traditional textbooks and teaching materials is a prerequisite for learning. Existing, at first glance, contradictions can be explained by the presence of various experiences in working with technical information, on the one hand, and the lack of proper skills for verifying this information and its classification in electronic media, on the other. The emergence of the latest ICT has its own specific features and necessitates the adaptation of students to the development of new technologies.

Despite the fact that about $80 \%$ indicate readiness for independent activity, $87.6 \%$ of respondents give a leading role to communication with the teacher in the process of professional competencies forming. At the same time, students need a permanent scientific and organizational guidance from the teacher, as a competent specialist in working with information.

Electronic media of information, however qualitative they may be, cannot replace the professional communication with the teacher, whose role in shaping the thinking of a future specialist engineer remains crucial. Only in communication with a professional a student can evaluate his level of competence and receive individual recommendations.

In fact, giving preference to edistance learning, we propose that the student independently handle the complex special information, the flow of which increases, resulting in overtraining, but not to its quality. In practice, we do not accidentally fix the student's desire to work with an electronic site, but provided that there are "live" individual consultations with the teacher, classroom lectures and practices. That is, students are adherents of a mixed learning system (full-time and distance).

The teacher remains the bearer of professional philosophy in the educational process, which forms the axiological reference points of a specialist.

On the other hand, the teacher is responsible for the quality of the information product, which must ensure the expected results of training a specialist engineer, as well as organize productive activities of personal training.

The impact of ICT on this process directly depends on the level of teaching, methodological and technical training of the teacher. Undoubtedly, information and communication technologies, as a means of training, improve the teaching process, improve its quality and effectiveness. However, this requires a significant cost of organizing training compared to traditional technologies, the ability to use software, the creation of additional methodological manuals and textbooks. In the absence of a clear methodology in developing the use of ICT for the education system, teachers are forced to focus on their understanding of the quality and effectiveness of the use of electronic technologies [22].

It should be emphasized that for the successful integration of technologies into the educational process, it is necessary to introduce a program of integrated professional training of teachers, which faces the task of rapid development and 
application of new learning technology.

Discussion. Numerous views, approaches and definitions of the current role of ICT in the educational process can still be divided into two groups. On the one hand, those who see the opportunities that provide information technology for communication, as progress in the development of education. On the other hand, those who focus on information risks: "in the information age, technological development has led to the fact that attention has shifted from the goals to the means" [25]. But they all united by the statement that currently traditional teaching methods are partially or completely replaced by new scientific methods, the basis of which is the active use of ICT. Therefore, it is worthwhile to focus on highlighting the advantages and disadvantages of using ICT in today's educational process.

Thus, according to the results of the survey, $88.7 \%$ of respondents believe that using an electronic learning site, they have the opportunity to receive the necessary information in a timely manner. Reducing the time for training, improving the quality of the expected result through the balanced use of computer communication is confirmed by studies [26]. The same is the opinion of experts [27], who believe that ICT serve the principle of lifelong learning, is, in addition, an effective means of introducing learning environments for individual individuals.
But despite the fact that $80 \%$ of respondents are ready for selfemployment using ICT, the need for a scientifically-organized leadership on the part of teachers is noted. The leading role of the teachers as organizers of the correct use of information technology tools in the learning process was noted in the research [28].

None of the respondents mentioned negative consequences of using ICT, but $56.3 \%$ of them consider that it is necessary to combine the use of ICT with the use of traditional textbooks. There are conclusions about the negative results of the implementation of ICT in the educational process. For example, some experts from Venezuelan universities [29] consider the use of the Internet to spread knowledge as destructive innovation. Such conclusions can be explained by the difficulties associated with the availability of Internet resources, which is a characteristic feature of the development of a particular country.

Interest is the results of research [30] on inhibition of communication skills with the development of information technology. Thus, interviewed respondents believe that ICT facilitate communication in the student-student group. But the habit of communicating mainly in the form of electronic correspondence leads to difficulties with the argumentation of their own thoughts when communicating with a teacher. This is a confirmation of the conclusion that the teacher plays a leading role in the development of professional competences and the giving the ICT

The role of information and communication technologies in the system of forming of professional competences of engineers 
important but minor role in this process.

\section{Conclusions}

1. During the study, it was confirmed that students of engineering direction are motivated by the use of ICT for independent work and connect this process not only with the formation of professional competences, but also with future professional activities.

2. The study showed the readiness of students to self-study using of ICT, which allows to change significantly the structure and organization of the educational process, improve the efficiency and quality of learning through the use of resources of the general educational environment, enhance the student's motivation for scientific and cognitive activity.

3. Despite the attractiveness of the ICT environment for students, the role of teacher in implementing a competent approach in the learning process remains the leading one. Electronic technology is an addition to traditional forms of learning, changing their content, methods and forms of organization.

4. The formation of professional competences for future engineers largely depends on the methodology of implementing ICT in the educational process for the implementation of educational, scientific and organizational activities, on the quality of ICT and on how systematically and carefully they are applied. Therefore, the question of the formation of ICT competence as an important component of the professionalism of both the teacher and the future engineer is relevant.

5. The focus of the education system on the education of a competent specialist should be based on a coherent system of educational process aimed at developing the innovative thinking of students and realizing the creative potential of the individual.

\section{REFERENCES}

1. Larionova, V. K. (2004). Filosofiya religiyi. Ivano-Frankivsk: Vidavnitstvo «Gostinets», 148.

2. Maslova, Yu. P. (2010). Religiyno-mifologichne pidrruntya gendernikh stereotipiv. Seriya «Istorichne religieznavstvo», 3, 143-148.

3. Ignatov, S. (2017). Bolee $20 \%$ stran mira imeyut ofitsialnuyu gosudarstvennuyu religiyu. Available at: https://www.sedmitza.ru/text/7549104.html

4. Ioann, P. II (2004). Idite s mirom. Dar bessmertnoy lyubvi. Moscow: OOO Izdatelskiy dom"Sofiya", 208.

5. Masatoshi, U. (2001). Gendernoeravenstvo v buddizme. New York: PiterLang, 191.

6. Gorshunova, O. V., Peshkova, S. A. (2013). Fertilnost i sakralnoe zhenskoe nachalo v sredneaziatskikh tselitelskikh i ritualnykh praktikakh. Meditsinskaya antropologiya i bioetika, $1(5)$.

7. Interaktivna karta religiynosti svitu. Available at: https://risu.org.ua/ua/index/all_news/community/social_questioning/69836/

8. Primery gendernogo neravenstva vovsem mire. Available at: https://www.infoniac.ru/news/Primery-gendernogo-neravenstva-vo-vsem-mire.html

9. Sostavlen reyting stran po urovnyu gendernogo ravenstva (2017). Available at: https://livingintravels.com/sostavlen-rejting-stran-po-urovnyu-gendernogo-ravenstvu 
10. Martsenyuk, T. (2015). Genderna rivnist i dolya zhinok v parlamentakh svitu. Available at: http://khpg.org/index.php?id=1437182774 [in Ukrainian]

11. Global Entrepreneurship Monitor 2016/2017. Report on Women's Entrepreneurship. Available at: https://www.babson.edu/Academics/centers/blank-center/globalresearch/gem/Documents/GEM\%202016-2017\%20Womens\%20Report.pdf [in English]

12. Bychkov, A. V., Mikushina, T. N., Skuratovskaya, M. L., Ilina, Ye.Yu. (2015). «Doktrina Vysokoy Nravstvennosti». Mezhdunarodnoe Obshchestvennoe Dvizhenie «ZA NRAVSTVENNOST!» Available at: http://www.z-n.center/index.htm

13. Stanovyshche simi v Yevropi: statystyka, shcho bie na spolokh. CREDO. Available at: http://credo.pro

14. Omer, Nasukhi Bilmen (2001). Bolshaya islamskaya nauchnaya entsiklopediya. Omer Nasukhi Bilmen. Neftechala.

15. Brak informatsiyi, prav ta hroshei. Chomu zhinky vse shche vmyraiut pid chas polohiv. Available at: https://nv.ua/ukr/world/countries/brak-informatsiji-prav-i-hroshejchomu-zhinki-vse-shche-vmirajut-pid-chas-polohiv-2496435.html

ВАСИЛЕНКО, Т. Г. - кандидат хімічних наук, доцент кафедри природничих наук, Запорізька державна інженерна академія (Запоріжжя, Україна)

E-mail: tatyana.vasilenko2012@gmail.com ORCID: 0000-0001-6166-0617

ДОБРОВОЛЬСЬКА, О. Г. - кандидат технічних наук, доцент кафедри міського будівництва та господарства, Запорізька державна інженерна академія (Запоріжжя, Україна)

E-mail: dogoks@gmail.com ORCID0000-0002-1337-7216

\section{РОЛЬ ІНФОРМАЦІЙНО-КОМУНІКАЦІЙНИХ ТЕХНОЛОГІЙ У СИСТЕМІ ФОРМУВАННЯ ПРОФЕСІЙНИХ КОМПЕТЕНЦІЙ ІНЖЕНЕРІВ}

Анотація. Актуальність проведеного дослідження носить практично орієнтований характер, оскільки застосування інформаційно-комунікаційних технологій (ІКТ)на сучасному етапі розвитку вищої освіти визначає якість підготовки фахівців інженерного профілю, результати професійної діяльності яких необхідні для реалізації національної стратегії модернізації економіки та формування прогресивної держави європейського типу Постановка завдання .Оскільки інженерна освіта набуває визначального значення в розвитку інноваційних систем, вона може розвиватися тільки в контексті складної системи IКТ, яка включає в себе не тільки програмне та технічне забезпечення, але і організаційні, психологічні та методологічні підходи. Це вимагає детального аналізу специфіки застосування IКТ в системі підготовки інженерних фахівців, а також готовності суб'єктів навчального процесу до активної участі у використанні і формуванні складного середовища, що включає безліч інформаційних об'єктів і зв'язків між ними. Структурно-функціональний аналіз застосування IКТ у вищій школі дозволяє теоретично обгрунтувати підходи до формування професіоналізму майбутніх інженерів та оцінити ризики, що пов'язані з впровадженням IКТ в навчальний процес.

Аналіз останніх досліджень і публікацій. Досвід використання ІКТ у вищій школі активно розглядається, можна виділити роботи закордонних фахівців Д. Стівенсона, Г. Рейнгольда, Е. Венгера, С. Пейперта, І. Захарової, С. Патаракіна, А. Хуторського, С. Полат. Засновниками цього наукового напряму в нашій країні були М . І. Жалдак, Ю. I.Машбиць. Нині помітно зросла кількість досліджень, предметом яких стало використання інформаційно-комунікаційних технологій у навчальному процесі. Цій темі в Україні присвячені дослідження таких науковців, як В. Ю. Биков, Я.В. Булахова, О.М. Бондаренко, В. Ф. Заболотний, Г. О. Козлакова, О. Мойко, О. Науменко, Ю.Буровицької, І. Ставицької, О. П. Пінчук, О. В. Шестопал та інших. Виділення недосліджених частин загальної проблеми. Сучасні економічні форми діяльності і перехід до інформаційного суспільства формують нові вимоги до підготовки

The role of information and communication technologies in the system of forming of professional competences of engineers 
інженерних фахівців. Стрімкий розвиток ІКТ забезпечує не тільки значні темпи інноваційного прогресу, але й вимагає впровадження інформаційних ресурсів, які гарантують якість навчання, вибір методик, що відповідають загальній стратегії формування професійних компетенцій інженера. Тому проблема вибору певних підходів до процесу навчання 3 використанням засобів ІКТ залишається однією 3 головних завдань освіти. Методи дослідження. У теорії і практиці дослідження застосування інформаційно-комунікаційних технологій (IКT) у вищій школі використовувались емпіричні методи збору та аналізу інформації за результатами анкетування 120 студентів. Виклад основного матеріалу. Розкрито сутність компетентнісного підходу в освіті майбутніх фахівців технічного напряму. Представлена наукова точка зору на підходи до формування професіоналізму інженера. Теоретично обгрунтовані особливості формування основ технічного професіоналізму інженерів в процесі навчання у вищій школі. Представлено кількісний і якісний аналіз результатів емпіричних досліджень даної проблеми. Результат дослідження. Для вирішення проблеми узгодженості ІКТ з методами викладання інженерних дисциплін у вищій школі слід створити концепцію стратегії розвитку креативних методів навчання, спрямованих на поєднання самостійної роботи студентів 3 використанням ІКТ та очного спілкування з викладачем. Висновки. ІКТ дозволяє істотно змінити структуру і організацію навчального процесу, підвищити ефективність і якість навчання за рахунок використання ресурсів загального освітнього середовища, підвищити мотивацію студента до науково-пізнавальної діяльності. Важлива якість та методологія впровадження ІКТ в освітній процес для реалізації навчальної, наукової і організаційної діяльності. Тому актуальним $є$ питання формування ІКТ-компетенції - важливої складової професіоналізму як викладача, так і майбутнього інженера. Практичне значення. Досліджуються інноваційні підходи до підготовки фахівців інженерних спеціальностей, проблеми і особливості впровадження IКТ в навчальний процес та мотивація майбутніх фахівців до самостійної діяльності в процесі формування професійних компетенцій.

Ключові слова: інженерна освіта;інформаційно-комунікаційні технології; професійні компетенції;мотивація в навчанні; компетентнісний підхід.

ВАСИЛЕНКО, Т. Г. - кандидат химических наук, доцент кафедры естественных наук, Запорожская государственная инженерная академия (Запорожье, Украина)

E-mail: tatyana.vasilenko2012@gmail.com, ORCID: 0000-0001-6166-0617

ДОБРОВОЛЬСКАЯ, О. Г. -- кандидат технических наук, доцент кафедры городского строительства и хозяйства, Запорожская государственная инженерная академия (Запорожье, Украина)

E-mail: dogoks@gmail.com, ORCID 0000-0002-1337-7216

\section{РОЛЬ ИНФОРМАЦИОННО-КОММУНИКАЦИОННЫХ ТЕХНОЛОГИЙ В СИСТЕМЕ ФОРМИРОВАНИЯ ПРОФЕССИОНАЛЬНЫХ КОМПЕТЕНЦИЙ ИНЖЕНЕРОВ}

Аннотация. Актуальность проведенного исследования носит практически ориентированный характер. Без применения информационно-коммуникационных технологий (ИКТ) в сфере высшего образования невозможно осуществлять качественную подготовку специалистов инженерного профиля, результаты профессиональной деятельности которых необходимы для реализации национальной стратегии модернизации экономики и формирования прогрессивного государства европейского типа. Постановка задачи - специфика применения ИКТ в системе высшего образования изучена недостаточно полно. ИКТ формируют сложную среду, включающую множество информационных объектов и связей между ними. Можно утверждать, что структурно-функциональный анализ применения ИКТ в высшей школе является основой теоретического обоснования в формировании технического 
профессионализма будущих инженеров. ИКТ образуют сложную систему, в которую входят не только технические и программно-аппаратные возможности, но и психологопедагогические, организационные, методологические. Без учета всех этих компонентов, а также потребностей субъектов учебного процесса, использование средств ИКТ (особенно централизованное) может сопровождаться рисками и негативно влиять на качество высшего образования. Анализ последних исследований и публикаций. Активно изучается опыт использования ИКТ в высшей школе, можно выделить работы иностранных специалистов Д. Стивенсона, Г. Рейнгольда, Е. Венгера, С. Пейперта, И. Захаровой, Е. Патаракина, А. Хуторского, Е. Полат. Учредителями этого научного направления в нашей стране были М. И. Жалдак, Ю. И. Машбиц. Сейчас заметно увеличилось количество исследований, предметом которых стало использование информационных-коммуникационных в учебном процессе. Этой теме в Украине посвящены исследования таких ученых, как В.Ю. Быков, Я.В. Булахова, А.Н. Бондаренко, В.Ф. Заболотный, Г.А. Козлакова, А. Мойко, А. Науменко, Ю.Буровицкая, И. Ставицкая, А.П. Пинчук, А.В. Шестопал и другие. Выделение неисследованных частей общей проблеме. Использование информационных технологий в образовательном процессе является фундаментом инновационного развития учебной системы. Стремительное развитие ИКТ обеспечивает не только значительные темпы инновационного прогресса, но и требует определения (ограничения) информационных ресурсов, которые гарантируют качество обучения, выбора методик, отвечающих общей стратегии формирования профессиональных компетенций. Поэтому проблема выбора подхода к процессу обучения с использованием средств ИКТ остается одной из главных заданий образования. Методы исследования. В теории и практике исследования применения информационно-коммуникационных технологий в высшей школе используются эмпирические методы сбора и анализа информации по результатам анкетирования 120 студентов. Изложение основного материала. Раскрыта сущность профессионализма будущих специалистов технического направления. Представлена научная точка зрения на профессионализм инженера. Теоретически обоснованы особенности формирования основ технического профессионализма будущих инженеров в процессе обучения в высшей школе. Представлены количественный и качественный анализ результатов эмпирических исследований данной проблемы. Результат исследования. Для решения проблемы согласованности ИКТ с методами преподавания инженерных дисциплин в высшей школе необходимо создать концепцию стратегии развития креативных методов обучения, направленных на сочетание самостоятельной работы студентов с использованием ИКТ и очного общения с преподавателем. Выводы. Для подготовки компетентных специалистов необходима системная целостность учебновоспитательного процесса при общей его ориентации на развитие инновационного мышления студентов и их креативных способностей. Практическое значение темы исследования в том, что исследуются инновационные подходы к подготовке специалистов инженерных специальностей, которые дифференцируются в образовательных концепциях обучения высших учебных заведений европейских стран.

Ключевые слова: инженерное образование, информационно- коммуникационные технологии; профессиональные компетенции; интегративно-деятельное обучение

Стаття рекомендована до публікаиії д.філософ.н., проф. В.Г.Воронковою (Запоріжжя, Україна) Надійшла до редколегії: 10.09.2018

Прийнята до друку: 15.09.2018

The role of information and communication technologies in the system of forming of professional competences of engineers 